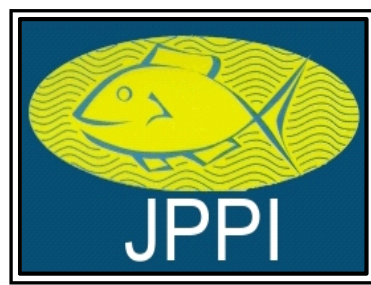

Tersedia online di: http://ejournal-balitbang.kkp.go.id/index.php/jppi

e-mail:jppi.puslitbangkan@gmail.com

JURNAL PENELITIANPERIKANANINDONESIA

Volume 26 Nomor 2 Juni 2020

p-ISSN: 0853-5884

e-ISSN: 2502-6542

Nomor Akreditasi RISTEKDIKTI: 21/E/KPT/2018

\title{
DINAMIKA PERIKANAN PELAGIS KECIL DENGAN PUKAT CINCIN DI PERAIRAN SAMUDERA HINDIA BARAT SUMATERA
}

\section{DYNAMICS OF SMALL PELAGIC FISHERIES BY PURSE SEINERS IN THE INDIAN OCEAN WEST OFF SUMATERA}

\author{
Helman Nur Yusuf ${ }^{\star 1}$, Baihaqi ${ }^{1}$ dan Hufiadi ${ }^{1}$ \\ ${ }^{1}$ Peneliti pada Balai Riset Perikanan Laut, Jakarta \\ ${ }^{1}$ Komplek Raiser Ikan Hias Cibinong. Jl. Raya Bogor KM. 47 Nanggewer Mekar, Cibinong, Bogor-16912, Indonesia \\ Teregistrasi I tanggal: 12 Mei 2020; Diterima setelah perbaikan tanggal: 15 Juni 2020; \\ Disetujui terbit tanggal: 18 Juni 2020
}

\begin{abstract}
ABSTRAK
Sumberdaya ikan pelagis kecil hasil tangkapan pukat cincin di perairan Samudera Hindia Barat Sumatera memberikan kontribusi penting terhadap produksi perikanan di wilayah tersebut setelah ikan pelagis besar. Supaya pemanfaatannya berkelanjutan maka diperlukan upaya pengelolaan sumber daya ikan berdasarkan kajian perikanan dan biologinya. Data bulanan selama Maret sampai Desember 2018 dikumpulkan dari TPI Lampulo (Banda Aceh) dan Sibolga (Sumatera Utara), bertujuan untuk memperoleh informasi dan menganalisis tentang dimensi alat tangkap, daerah penangkapan ikan, komposisi hasil tangkapan, frekuensi ukuran ikan dan upaya penangkapan (hasil per unit upaya, CPUE). Selanjutnya data biologi ikan dianalisis dengan metode analitik. Hasil penelitian menunjukkan perubahan dimensi pukat cincin yang digunakan. Jenis ikan layang (Decapterus macarellus) merupakan hasil tangkapan dominan yang didaratkan di PPS Lampulo (Banda Aceh) dan PPN Sibolga (Sumatera Utara), masing-masing sebesar 82,2\% dan $51 \%$ dari total produksi ikan tahun 2018 di daerah tersebut. Jenis lainnya meliputi: lemuru (Sardinella lemuru), selar kuning (Selaroides leptolepis), sunglir (Elagatis bipinnulata), kembung (Rastrelliger kanagurta), tembang (Sardinella fimbriata) dan selar bentong (Selar crumenophthalmus) dengan proporsi berkisar antara 4,8 - $28 \%$. Daerah penangkapan ikan semakin jauh dari biasanya. Panjang pertama kali tertangkap (length at first capture, Lc) ikan layang sebesar $24 \mathrm{cmFL}$, selar bentong $17 \mathrm{cmFL}$ dan tembang $16 \mathrm{cmFL}$. Hasil per unit upaya (CPUE) pukat cincin di TPI Lampulo dan Sibolga masing-masing sebesar 263 kg/hari dan 316 kg/ hari.
\end{abstract}

Kata Kunci: Dinamika perikanan; pukat cincin; ikan pelagis kecil; Barat Sumatera

\section{ABSTRACT}

Small pelagic fish resources caught by purse seiners in the Indian Ocean west off Sumatera contribute an important fish production in those areas after large pelagic fish. Management of fish resources based on fishery and biological informations need to be done to optimize its utilization. Monthly data collected during March to December 2018 were obtained at landing places of Lampulo (Banda Aceh) and Sibolga (North Sumatera). The aims of this research were to determine of dimention of fishing gear, fishing grounds, catch composition, size frequencies of fish and catch per unit of effort (CPUE). The data of characteristic biology were analyzed using an analytical model. The results showed that dimention in length and depth of purse seine has changed. Round scad (Decapterus macarellus) as dominant fish landed at Lampulo and Sibolga landing places with $82.2 \%$ and $51 \%$ of total production, respectively. The rest, with proportions ranged between 4.8 to $28.0 \%$ included sardine (Sardinella lemuru), yellow stripe trevally (Selaroides leptolepis), Rainbow runner (Elagatis bipinnulata), Indian mackerel (Rastrelliger kanagurta), Fringescale sardinella (Sardinella fimbriata), Bigeye scad (Selar crumenopthalmus). At present, fishing grounds are getting further from the coast. Length at first capture $(L C)$ of $D$. macarellus was $24 \mathrm{cmFL}, S$.

Korespondensi penulis:

helmankkp183@gmail.com

DOI: http://dx.doi.org/10.15578/jppi.26.2.2020.109-123 
fimbriata was $17 \mathrm{cmFL}$, and S. crumenophthalmus was $16 \mathrm{cmFL}$. The catch per unit of effort by purse seiners in Lampulo and Sibolga were $263 \mathrm{~kg} /$ day and $316 \mathrm{~kg} /$ day, respectivelly.

\section{Keywords: Fishery dynamics; purse seine; small pelagic fish; West Sumatra}

\section{PENDAHULUAN}

Sumber daya ikan pelagis kecil merupakan salah satu komoditas penting di Wilayah Pengelolaan Perikanan Negara Republik Indonesia 572 (WPPNRI 572). Pada tahun 2014, kontribusi yang didaratkan melalui PPS Lampulo dan PPN Sibolga mencapai $66,2 \%$ dari total produksi ikan yang didaratkan (Suman et al., 2014). Potensi ikan pelagis di Samudera Hindia barat Sumatera sesuai KepMen-KP no. 50 tahun 2017 sebesar 527.029 ton dengan jumlah tangkapan yang diperbolehkan sebesar 421.623 ton atau 80\% JTB dengan tingkat pemanfaatan sebesar 0,5 (KepmenKP No. 50,2017$)$. Sedangkan potensi ikan pelagis yan telah dimanfaatkan sebesar $90.106,9$ ton $17,09 \%$ dari jumlah tangkapan yang diperbolehkan (JTB) ikan pelagis kecil di WPP 572 (BRPL, 2018).

Ikan pelagis ditangkap utamanya dengan pukat cincin yang mulai berkembang sejak tahun 1970 an. Nurhakim et al. (2007) menyatakan bahwa periode 1995-1997 belum diperoleh informasi mengenai perkembangan perikanan pukat cincin di wilayah Laut Andaman dan Selat Malaka. Berdasarkan penelitian yang dilakukan Hartati (2011), dinyatakan bahwa pada periode itu, proses penangkapan pukat cincin dilakukan dengan dua cara, yaitu mengejar gerombolan ikan pelagis besar pada siang hari dan mengumpulkan ikan pelagis kecil dengan bantuan sinar lampu yang dipasang pada malam hari. Jenis hasil tangkapan yang diperoleh dari cara pertama terdiri atas kelompok ikan pelagis besar seperti ikan cakalang (Katsuwonus pelamis), mandidihang (Thunnus albacares), tongkol (Euthynnus affinis) dan lain-lain (Bahar, 1994), sedangkan dari cara kedua diperoleh jenis-jenis ikan pelagis kecil seperti ikan layang (Decapterus sp.), selar (Carangidae sp.), banyar (Rastrelliger kanagurta), siro (Amblygaster sirm), dan tembang (Sardinella fimbriata) (Hariati et al., 2001). Penangkapan menggunakan kedua cara tersebut menghasilkan kelompok jenis-jenis ikan yang sesuai dengan sasaran.

Produksi perikanan pelagis kecil di Lampulo pada periode 2006-2018 adalah sekitar 47.190,3 ton, dengan komposisi hasil tangkapan diantaranya ikan layang (Decapterus macarellus), selar (Caranx sp), lemuru (Sardinella lemuru), kembung (Rastrelliger kanagurta), tembang (Sardinella fimbriata), kambingkambing (Canthidermis maculata), cumi-cumi
(Photololligo duvaucelli), dan sunglir (Elagatis bipinnulata). Sedangkan produksi pelagis kecil Sibolga pada periode 2010 - 2018 sekitar 42.916,6 ton dengan komposisi terdiri atas ikan layang (Decapterus macarellus), kembung (Rastrelliger kanagurta), tembang (Sardinella fimbriata), selar bentong (Selar crumenophthalmus), japuh (Dussumieria acuta), dan tetengkek (Megalaspis cordyla). Dominasi hasil tangkapan pelagis kecil periode 2006-2018 sepertinya tidak mengalami perubahan yang berarti. Hal ini seperti yang diutarakan Hariati et al. (2001) mengatakan bahwa hasil tangkapan ikan pelagis kecil barat Sumatera didominasi ikan layang (Decapterus sp.), selar (Carana spp.), kembung (Rastrelliger kanagurta), siro (Amblygaster sirm), dan tembang (Sardinella fimbriata).

Secara umum, komposisi hasil tangkapan ikan pelagis kecil tidak mengalami perubahan. Namun dari sisi daerah penangkapan dari tahun ke tahun adanya perubahan atau pergeseran ke wilayah yang lebih jauh, baik daerah penangkapan nelayan Sibolga atau nelayan Lampulo, perubahan dimensi alat tangkap, nilai CPUE, perubahan kisaran panjang ikan. Hal ini yang mendasari penulis untuk mengkaji dinamika perikanan pelagis kecil di perairan barat Sumatera.

\section{BAHAN DAN METODE Pengumpulan Data}

Penelitian perikanan pelagis kecil di perairan barat Sumatera dilakukan di PPS Lampulo dan PPN Sibolga Samudera Hindia barat Sumatera (Gambar 1), dalam periode Maret sampai dengan Desember 2018. Hasil observasi selama penelitian diperoleh data yaitu data spesifikasi kapal, dimensi alat tangkap, jumlah kapal yang mendaratkan hasil tangkapan, spesies dominan, ukuran kapal, operasional, daerah penangkapan perikanan pelagis kecil dan untuk menunjang informasi tersebut dilakukan wawancara atau diskusi dengan nakhoda dan anak buah kapal.

Data yang dianalisis yaitu data hasil tangkapan kapal pukat cincin, jumlah trip kapal diperoleh dari PPS Lampulo dan PPN Sibolga. Distribusi ukuran panjang cagak ikan atau fork length berdasarkan ukuran mata jaring dan kedalaman renang ikan dianalisis secara diskriptif. 


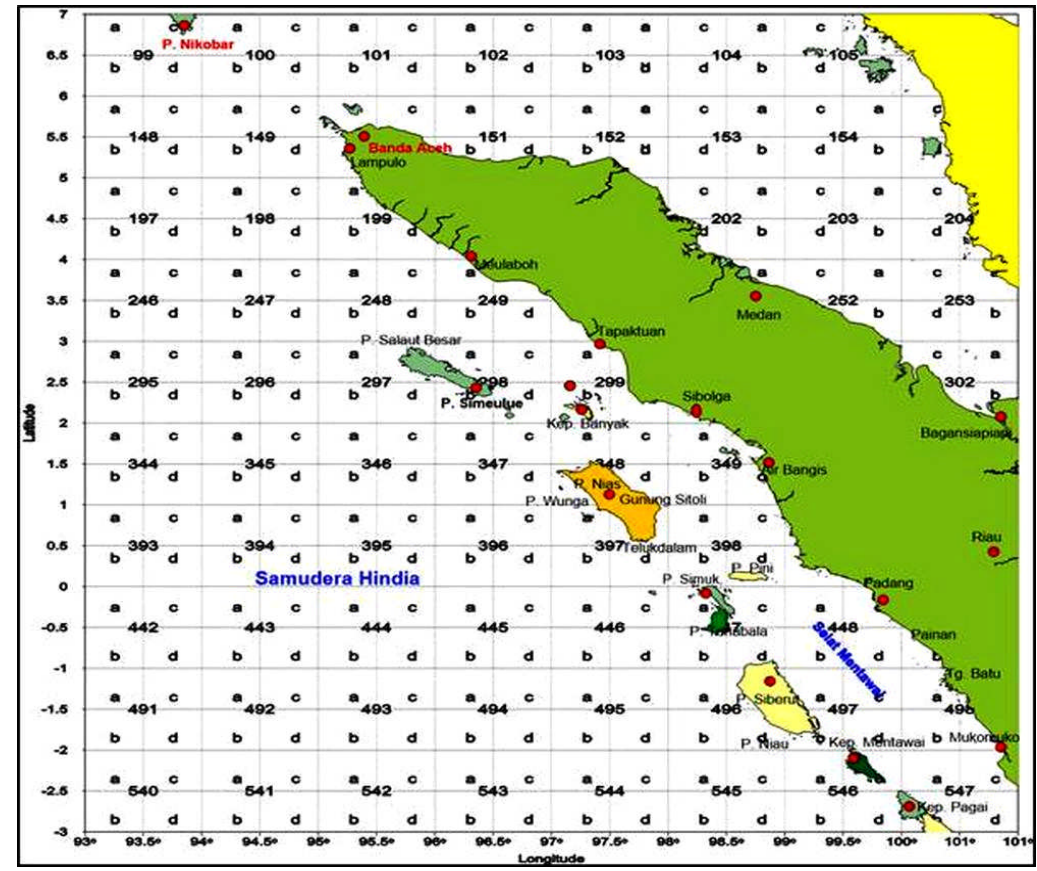

Gambar 1. Daerah Penelitian Pelagis Kecil di Samudera Hindia barat Sumatera.

Figure 1. Research area of small pelagic in the Indian Ocean west off Sumatera.

\section{Analisa Data}

Analisis indek kelimpahan ikan (Catch per unit of effort/CPUE) diperoleh berdasarkan data hasil tangkapan yang didaratkan pada Januari sampai Desember 2018 dengan analisis deskriptif dan fluktuasi CPUE, upaya penangkapan, distribusi ukuran panjang cagak/fork length. Identifikasi spesies berdasarkan pendekatan Munro \& Wongratana (1999) dan Gloerfelt \& Kailola (1980).

Distribusi ukuran panjang cagak ikan atau fork length berdasarkan ukuran mata jaring dan kedalaman renang ikan dianalisis secara diskriptif. Untuk melihat perbedaan rata-rata ukuran ikan dengan mengunakan metode statistik melalui uji nilai tengah dengan dugaan keragaman yang berbeda. Proses perhitungan ratarata ikan pelagis pertama kali tertangkap $\mathrm{L}_{c}$ atau $\mathrm{L}_{50 \%}$ dengan pendekatan seperti gillnet yaitu dengan cara dilingkarkan (encircling gillnet and purse seine) yaitu dengan selektivitas pada kelolosan dengan model Holt seperti yang diutarakan Sparred an Venema (1999) sebagai berikut:

$$
S_{L}=\exp \left[-\frac{\left(L-L_{m}\right)^{2}}{2 * S^{2}}\right]
$$

Dimana:

$S_{L}=$ ikan dengan kisaran panjang $L$ tertahan di pukat cincin $\left(0<S_{L} d \leq 1\right)$
$L_{m}=$ kisaran panjang optimum ikan yang tertangkap

$S=$ standar deviasi dan distribusi normal

\section{HASIL DAN BAHASAN Hasil}

\section{Armada Pukat Cincin}

Spesifikasi salah satu armada pukat cincin bertonase 59GT di PPS Lampulo menunjukkan kapal terbuat dari kayu, berukuran panjang $(\mathrm{L})=28 \mathrm{~m}$, lebar (B) $=5 \mathrm{~m}$ dan dalam $(\mathrm{D})=3,5 \mathrm{~m}$. Mesin induk berkekuatan 160 PK dengan merk Mitsubishi 6 D16, genset (listrik) adalah Mitsubishi 42 PK, jumlah ABK sebanyak 25 orang. Ukuran satu pis jaring mempunyai panjang ris atas $1200 \mathrm{~m}$. PE $\varnothing 14 \mathrm{~mm}$, PE Ø $14 \mathrm{~mm}$ dan $\varnothing 7 \mathrm{~mm}$ dan panjang ris bawah $1320 \mathrm{~m}$ (Gambar 2).

Spesifikasi armada pukat cincin berukuran 59 GT terbuat dari kayu di PPN Sibolga mempunyai ukuran panjang $(L)=27 \mathrm{~m}$, lebar $(B)=4,5 \mathrm{~m}$ dan dalam $(D)=$ $3 \mathrm{~m}$. Mesin induk berukuran $280 \mathrm{PK}$ dengan merk Nissan, genset (listrik) adalah Mitsubishi 18 PK, jumlah ABK sebanyak 28-32 orang. Ukuran satu pis jaring mempunyai panjang ris atas $600 \mathrm{~m}$. PE $\varnothing 14$ $\mathrm{mm}$, PE $\varnothing 14 \mathrm{~mm}$ dan $\varnothing 7 \mathrm{~mm}$ dan panjang ris bawah $660 \mathrm{~m}$ (Gambar 3). Spesifikasi kapal dan aspek operasionalnya diterakan pada Lampiran 1. 


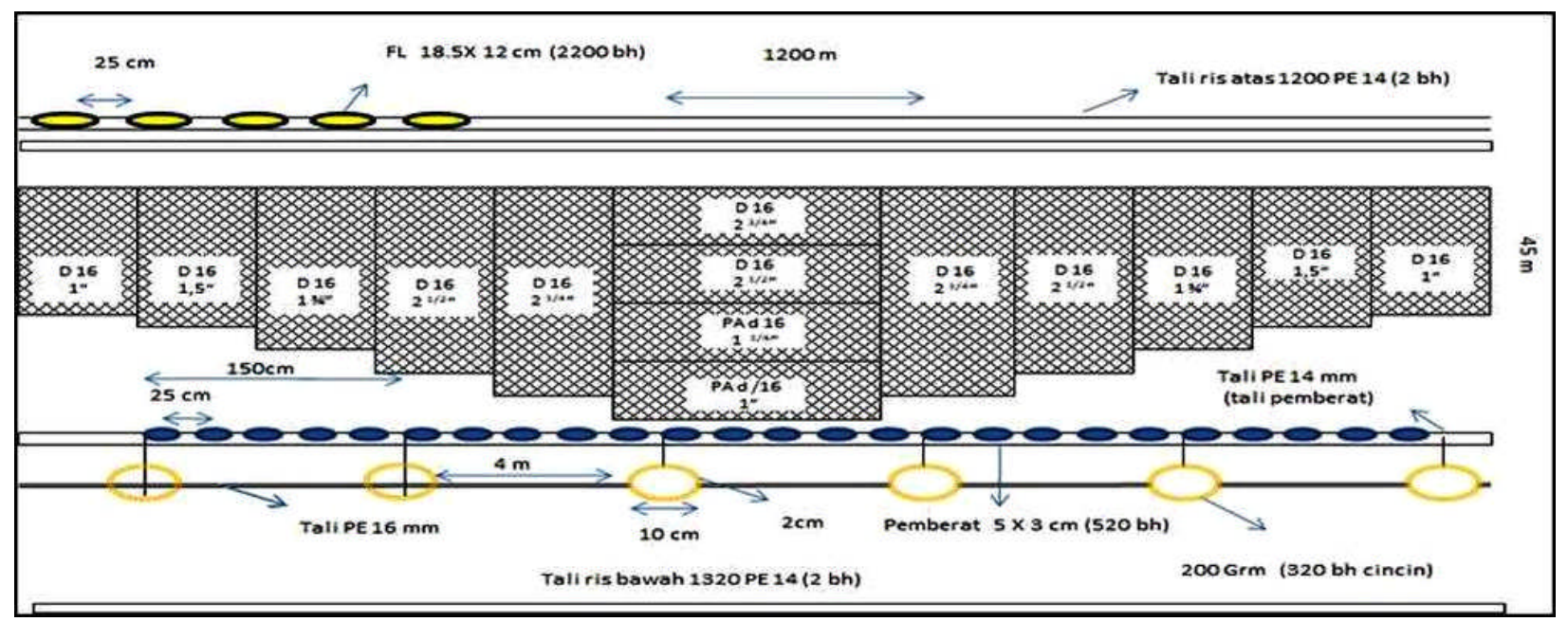

Gambar 2. Desain pukat cincin pada armada berukuran 59GT di PPS Lampulo.

Figure 2. Design of purse seine net at fishing vessel of 59GT from PPS Lampulo.

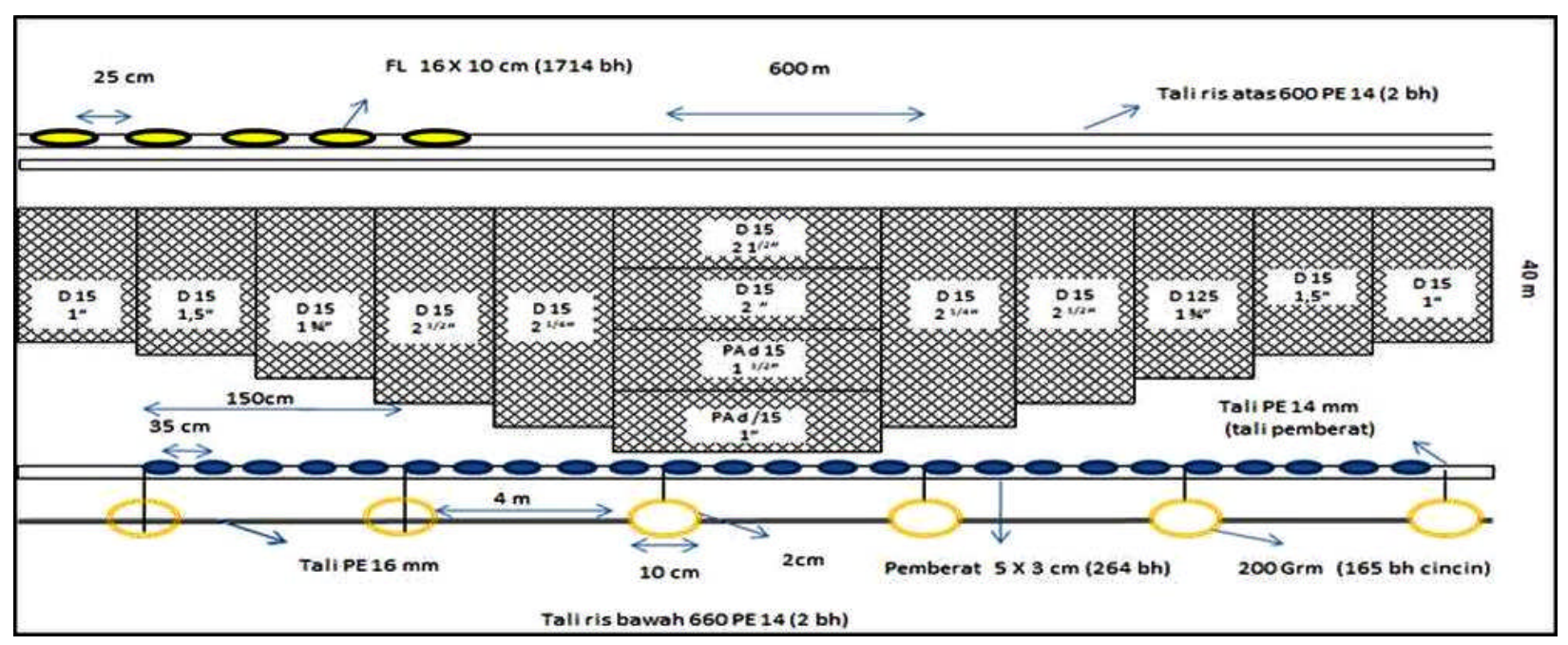

Gambar 3. Desain pukat cincin armada berukuran 59GT PPN Sibolga.

Figure 3. Design of purse seine net at fising vessel of 59GT from PPN Sibolga.

Pada tahun 2018 Produksi ikan pelagis kecil Lampulo, sedangkan di Sibolga sebesar $29,8 \%$ atau sebesar $50,24 \%$ atau $6.248,7$ ton dari total hasil $7.377,7$ ton (Tabel 1 ). tangkapan pukat cincin yang di daratkan di PPS

Tabel 1. Produksi ikan pelagis kecil berdasarkan gross tonnase di Lampulo dan Sibolga, 2018 Table 1. Small pelagic production based on gross tonnage in Lampulo and Sibolga, 2018

\begin{tabular}{|c|c|c|c|c|}
\hline \multirow{2}{*}{$\begin{array}{l}\text { GT / Gross } \\
\text { Tonnage }\end{array}$} & \multicolumn{2}{|c|}{$\begin{array}{c}\text { Produksi Pukat Cincin/ Production Of } \\
\text { Purse Seine (kg) }\end{array}$} & \multicolumn{2}{|c|}{$\begin{array}{c}\text { Produksi Pelagis Kecil/ } \\
\text { Production Small Pelagic (kg) }\end{array}$} \\
\hline & Lampulo & Sibolga & Lampulo & Sibolga \\
\hline $\begin{array}{c}\leq 5 \\
6-10 \\
11-20 \\
21-30 \\
31-50 \\
51-60 \\
61-100 \\
>100 \\
\text { Kapal tdk GT }\end{array}$ & $\begin{array}{c}172.239 \\
73.300 \\
320.333 \\
750.421 \\
1.054 .107 \\
476.516 \\
445.329 \\
9.145 .164\end{array}$ & $\begin{array}{c}103.670 \\
397.570 \\
1.181 .460 \\
12.444 .610 \\
10.625 .680\end{array}$ & $\begin{array}{c}\text { Coverage } \\
50,24 \% \\
\text { dari total } \\
\text { produksi }\end{array}$ & $\begin{array}{c}\text { Coverage } 29,81 \% \text { dari } \\
\text { total produksi }\end{array}$ \\
\hline $\begin{array}{l}\text { Total Produksi } \\
\text { Pukat Cincin }\end{array}$ & 12.437 .409 & 24.752 .990 & 6.248 .776 & 7.377.725 \\
\hline & & Coverage & $50,24 \%$ & $29,81 \%$ \\
\hline
\end{tabular}




\section{Daerah Penangkapan}

Daerah penangkapan ikan (DPI) armada pukat cincin berbasis Lampulo berada di perairan sebelah barat Aceh dan Laut Andaman pada jarak antara 2040 mil laut atau jarak tempuh antara 5-8 jam dengan lama trip penangkapan antara 2-3 hari. Bagi armada berukuran besar (>30GT) daerah penangkapannya mencapai perairan di perbatasan dengan Thailand atau di sekitar ZEEI bahkan di sekitar Kepulauan Nicobar pada jarak antara 100-250 mil laut dengan waktu tempuh antara 1-2 hari dan lama trip penangkapan berkisar antara 7-14 hari. Untuk memudahkan pendataan, dibuat peta DPI dengan sistem grid pada garis lintang dan bujurnya, dimana satu grid sebesar 0,5 derajat. Penomoran kolom grid sesuai dengan Sistem pendataan DPI dari e-BRPL. Peta penentuan DPI ini kemudian diisi oleh nakhoda atau enumerator di masing-masing lokasi.

Analisis DPI armada berbasis Lampulo sebagian besar berada pada grid-101 sebanyak 1.017 buah $(50,6 \%)$, diikuti oleh grid-100 sebanyak 734 buah (36,5\%), grid-98 sebanyak 96 buah (4,8\%), grid-97 sebanyak 83 buah $(4,1 \%)$, grid- 51 sebanyak 24 buah $(1,2 \%)$ dan grid lainnya (Tabel 2$)$.

Tabel 2. Jumlah armada pukat cincin berdasarkan daerah penangkapan ikan berbasis Lampulo, 2018 Table 2. Number of purse seiners by fishing ground based at Lampulo, 2018

\begin{tabular}{|c|c|c|c|c|c|c|c|c|c|c|c|}
\hline \multirow{2}{*}{ Grid } & \multicolumn{9}{|c|}{ Bulan/ Month } & \multirow[t]{2}{*}{ Total } & \multirow[t]{2}{*}{$\begin{array}{c}\text { Persentase } \\
(\%)\end{array}$} \\
\hline & Apr & Mei & Jun & Jul & Agt & Sept & Okt & Nov & Des & & \\
\hline Grid 98 & & & & & & & 2 & & & 2 & 0,1 \\
\hline Grid 99 & & 2 & & & & & & & & 2 & 0,1 \\
\hline Grid 147 & & & & & 5 & & & & & 5 & 0.2 \\
\hline Grid 102 & 7 & & & & & & & & & 7 & 0,3 \\
\hline Grid 146 & & & & & 7 & & & & & 7 & 0.3 \\
\hline Grid 52 & 6 & 10 & & & & & & & & 16 & 0,8 \\
\hline Grid 50 & 8 & 10 & & & & & & & & 18 & 0,9 \\
\hline Grid 51 & 8 & 16 & & & & & & & & 24 & 1,2 \\
\hline Grid 97 & & & & & 8 & 5 & 6 & 32 & 32 & 83 & 4,1 \\
\hline Grid 98 & & & & & 10 & 5 & 9 & 26 & 46 & 96 & 4,8 \\
\hline Grid 100 & 67 & 114 & & 3 & 69 & 114 & 128 & 131 & 108 & 734 & 36,5 \\
\hline Grid 101 & 96 & 153 & 28 & 40 & 160 & 120 & 99 & 161 & 160 & 1.017 & 50,6 \\
\hline Total & 192 & 305 & 28 & 43 & 259 & 244 & 244 & 350 & 346 & 2011 & 100 \\
\hline
\end{tabular}

Armada pukat cincin berbasis Sibolga berukuran antara 20-60 GT mempunyai DPI di sebelah barat Sumatera, sekitar Kepulauan Nias, Kep. Siberut, P. Simeulue dan P. Mentawai dengan jarak tempuh antara 6-12 jam dan trip penangkapan 7-15 hari. Bagi armada berukuran 100-200GT mempunyai DPI lebih ke tengah mencapai daerah ZEEI dengan trip penangkapan antara 3-6 bulan.

Analisis DPI menunjukkan sebagian besar berada di daerah grid-249 sebanyak 24 buah (17\%), diikuti grid-348 sebanyak 19 buah $(13,5 \%)$, grid-349 sebanyak 17 buah (12,1\%), grid-298 dan 248 sebanyak 15 buah (10,6\%), grid-398 sebanyak 12 buah (8,5\%), grid-448 sebanyak 11 buah (7,8\%) dan grid lainnya (Tabel 3). Peta DPI armada pukat cincin diperairan Samudera Hindia Barat Sumatera dijelaskan pada Gambar 4.

Sebaran daerah penangkapan pukat cincin Lampulo dan Sibolga berdasarkan kunjungan setiap kapal penangkap pertripnya (Gambar 4). Dimana kunjungan daerah penangkapan ikan pelagis sesuai dengan Tabel 2 dan Tabel 3. 
Tabel 3. Jumlah armada pukat cincin berdasarkan daerah penangkapan ikan berbasis Sibolga, 2018 Table 3. Number of purse seiners by fishing ground based at Sibolga, 2018

\begin{tabular}{|c|c|c|c|c|c|c|c|c|c|}
\hline \multirow[t]{2}{*}{ Grid } & \multicolumn{7}{|c|}{ Bulan/Month } & \multicolumn{2}{|r|}{$\begin{array}{c}\text { Persentase } \\
(\%)\end{array}$} \\
\hline & Mei & Juni & Juli & Agt & Sept & Okt & Nov & Total & \\
\hline Grid 299 & & & 1 & 1 & & & & 2 & 1,4 \\
\hline Grid 344 & & & 1 & 1 & & & & 2 & 1,4 \\
\hline Grid 347 & & & 1 & 1 & 1 & & 1 & 4 & 2,8 \\
\hline Grid 394 & & & 2 & 2 & & & & 4 & 2,8 \\
\hline Grid 496 & & 2 & 2 & 2 & & & & 6 & 4,3 \\
\hline Grid 447 & 4 & 1 & 1 & 1 & 1 & 1 & 1 & 10 & 7,1 \\
\hline Grid 448 & 1 & 2 & 3 & 3 & 1 & 1 & & 11 & 7,8 \\
\hline Grid 398 & & 1 & 3 & 3 & 1 & 2 & 2 & 12 & 8,5 \\
\hline Grid 248 & 1 & & 5 & 5 & 1 & 3 & & 15 & 10,6 \\
\hline Grid 298 & 3 & & 4 & 4 & 1 & 2 & 1 & 15 & 10,6 \\
\hline Grid 349 & 7 & 1 & 1 & 5 & 1 & 1 & 1 & 17 & 12,1 \\
\hline Grid 348 & 4 & 1 & 4 & 4 & 3 & 1 & 2 & 19 & 13,5 \\
\hline Grid 249 & 3 & 4 & 4 & 4 & 3 & 3 & 3 & 24 & 17,0 \\
\hline Total & 23 & 12 & 32 & 36 & 13 & 14 & 11 & 141 & 100,0 \\
\hline
\end{tabular}

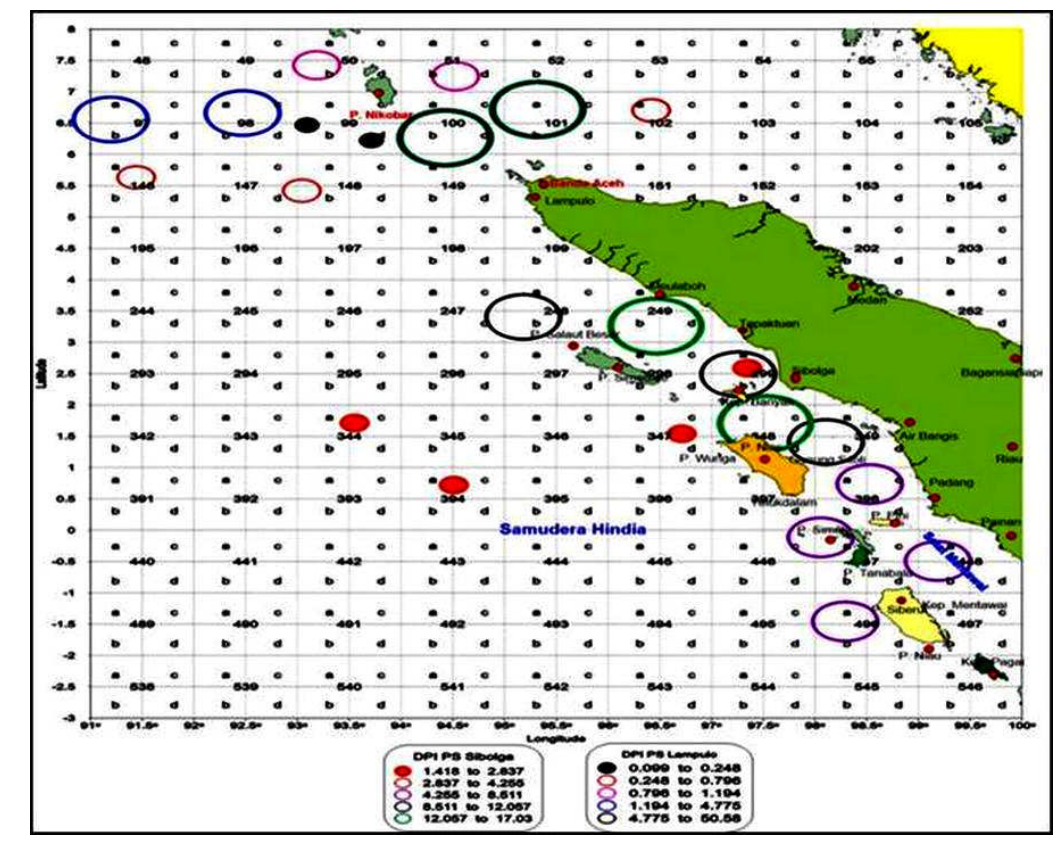

Gambar 4. Daerah penangkapan ikan dengan pukat cincin berbasis Lampulo dan Sibolga.

Figure 4. Fishing ground of purse seiner operation based at Lampulo and Sibolga.

\section{Komposisi Hasil Tangkapan}

Berdasarkan data enumerator dan produksi PPS Lampulo tahun 2018, komposisi ikan pelagis kecil yang tertangkap dengan pukat cincin di perairan Andaman sebanyak 9 spesies yaitu ikan layang $83,5 \%$, layang abu-abu/deles $5,3 \%$, pogot/kambingkambing $3,9 \%$, siro $2,0 \%$, selar $1,7 \%$, sunglir $1,4 \%$, kembung $0,6 \%$, cumi-cumi $0,5 \%$ dan ikan campur 2,4\% (Gambar 5).
Berdasarkan data enumerator dan produksi PPN Sibolga tahun 2018, komposisi ikan pelagis kecil yang tertangkap dengan pukat cincin di perairan Sibolga dan sekitarnya yaitu ikan layang mencapai 73\% sementara hasil tangkapan ikan pelagis lainnya berkisar antara1 sampai 10\% (Gambar 6 ). 
Dinamika..........Dengan Pukat Cincin di Perairan Samudera Hindia Barat Sumatera (Yusuf, H.N., et al)

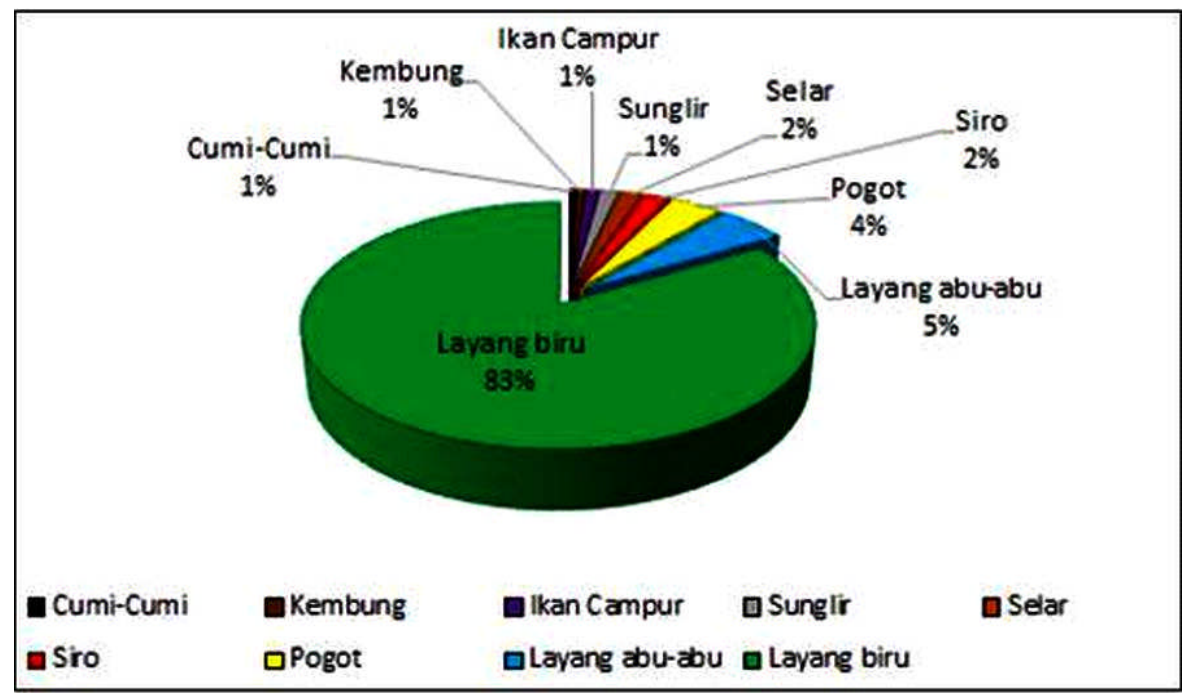

Gambar 5. Komposisi jenis ikan pelagis kecil yang tertangkap pukat cincin di perairan Andaman pada 2018. Figure 5. Composition species fish small pelagic caught by the purse seine nets Andaman waters in 2018.

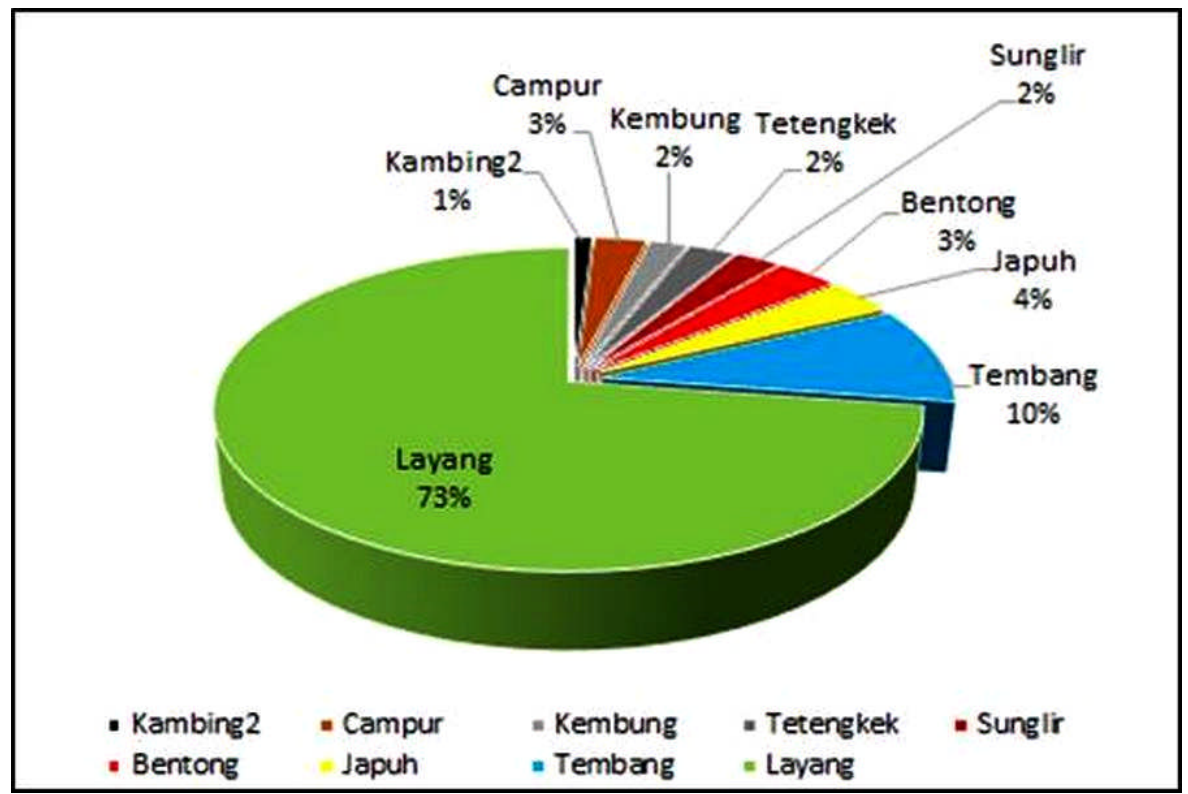

Gambar 6. Komposisi jenis ikan pelagis kecil yang tertangkap pukat cincin di perairan Sibolga pada 2018. Figure 6. Species composition of fish small pelagic caught by the purse seine in Sibolga waters in 2018.

\section{Ukuran Panjang Ikan}

Sebaran frekuensi panjang jenis ikan pelagis kecil di perairan barat Sumatera yang tertangkap dengan pukat cincin pada tahun 2018 yaitu ikan layang biru (Decapterus macarellus) berkisar antara 12,2-39,4 $\mathrm{cm}$ FL dengan nilai ukuran rata-rata pertama kali tertangkap (Lc) $24,27 \mathrm{~cm}$, selar bentong (Selar crumenopthalmus) berkisar antara $12,0-23 \mathrm{~cm}$ FL dengan nilai Lc $17,45 \mathrm{~cm}$ FL, dan tembang (Sardinella fimbriata) berkisar antara 11,3-24 dengan nilai LC masing-masing 16,6 cmFL (Gambar 7).

\section{Produksi dan Upaya Penangkapan}

Produksi ikan pelagis kecil dari perairan Laut Andaman yang didaratkan di PPS Lampulo menunjukkan kecenderungan yang meningkat selama tahun 2006-2018. Demikian pula jumlah trip penangkapannya. Produksi tertinggi 493.248 ton dicapai pada tahun 2018 dan terendah 259.808 ton dicapai pada tahun 2014. Jumlah trip penangkapan dengan pukat cincin tertinggi 2263 trip dicapai pada tahun 2013 dan terendah 2064 trip dicapai pada tahun 2006 (BRPL, 2018). Perkembangan produksi ikan pelagis kecil dan jumlah trip pukat cincin di Lampulo dikemukakan pada Gambar 8. 


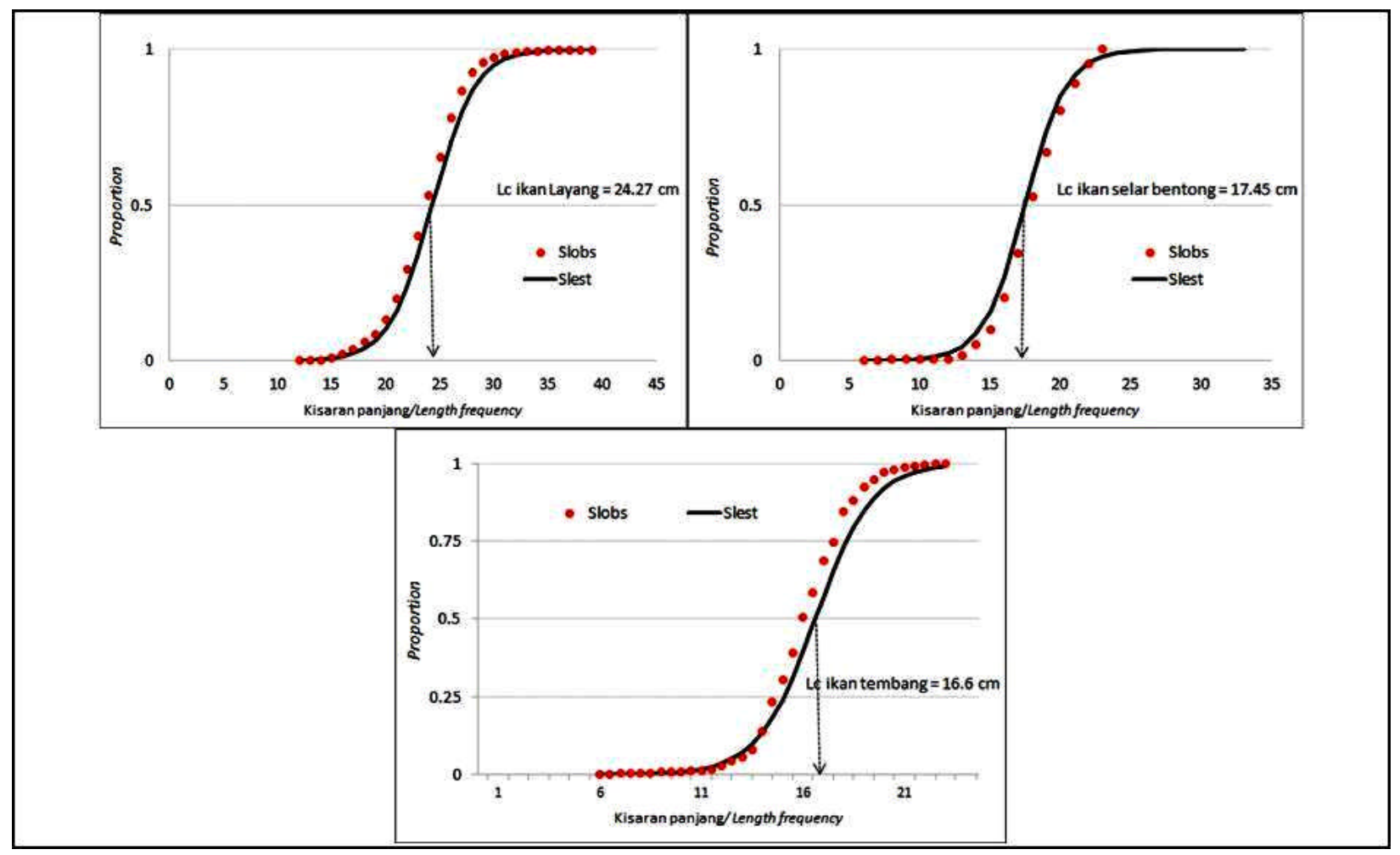

Gambar 7. Ukuran rata-rata pertama kal tertangkap (Lc) (Decapterus macarellus) (Selar crumenopthalmus) dan (Sardinella fimbriata) diperairan Samudera Hindia barat Sumatera.

Figure 7. Length at first captured (LC) (Decapterus macarellus) (Selar crumenopthalmus) dan (Sardinella fimbriata) in the Indian Ocean west off Sumatera.

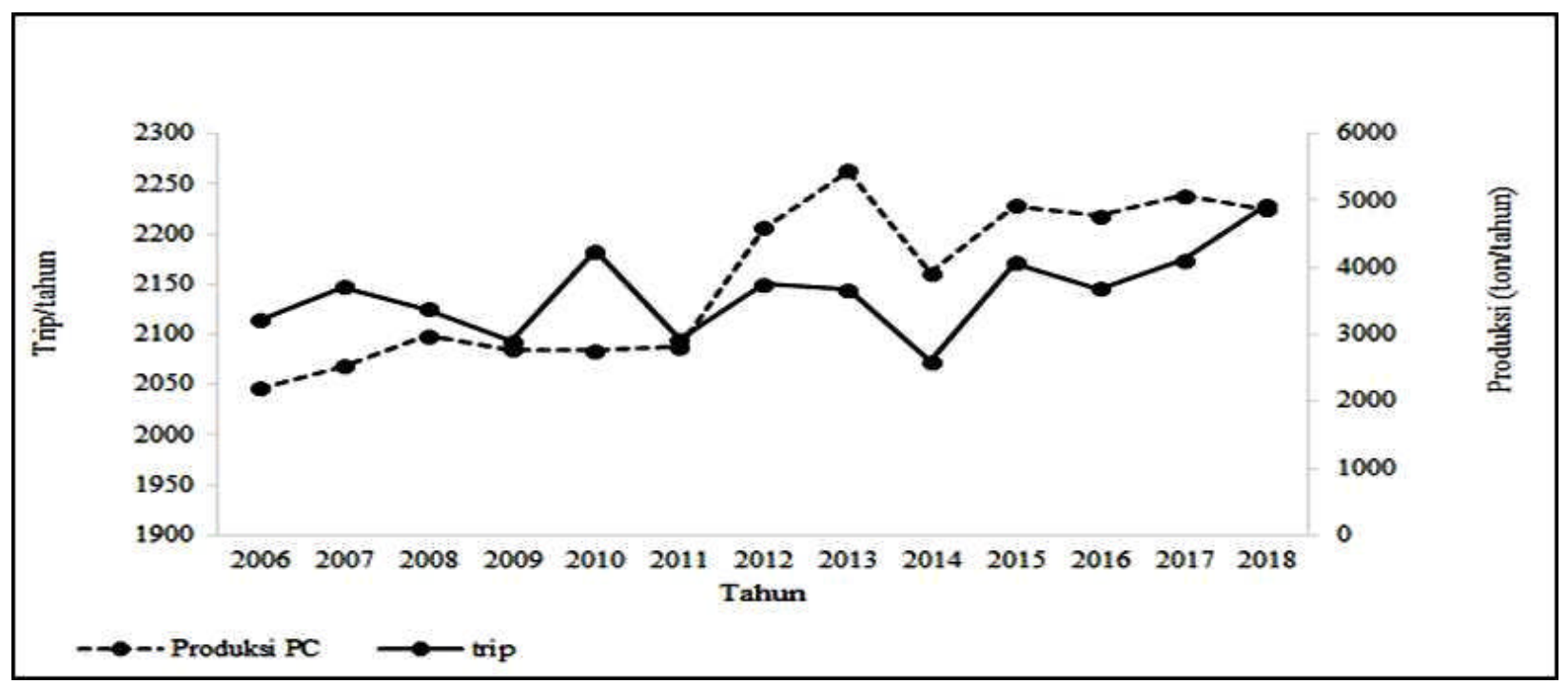

Gambar 8. Fluktuasi produksi ikan pelagis kecil dan jumlah trip pukat cincin yang didaratkan di PPS Lampulo, 2006-2018.

Figure 8. Fluctuation of production of small pelagic fish and number of trips by purse seiners landed at PPS Lampulo, 2006-2018.

Produksi ikan pelagis kecil dari perairan Barat Sumatera yang didaratkan di PPN Sibolga menunjukkan kecenderungan yang meningkat selama tahun 2010-2018. Demikian pula jumlah trip penangkapannya. Produksi tertinggi (7271 ton) dicapai pada tahun 2018 dan terendah (1778 ton) dicapai pada tahun2013. Jumlah trip penangkapan dengan pukat cincin yang tertinggi (1850 trip) dicapai pada tahun 2018 dan terendah (317 trip) dicapai pada tahun 2010 (BRPL, 2018). Perkembangan produksi ikan pelagis kecil dan jumlah trip pukat cincin di Sibolga dikemukakan pada Gambar 9. 


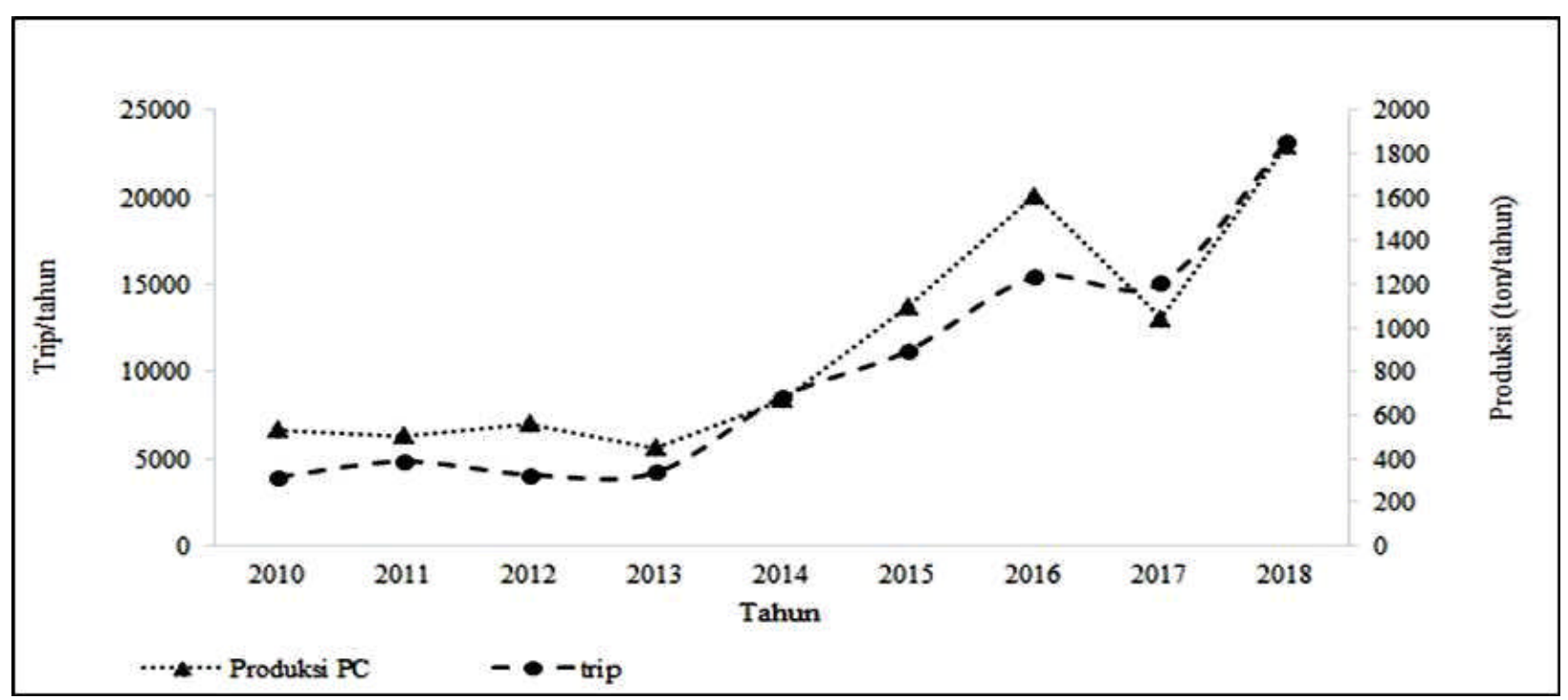

Gambar 9. Fluktuasi produksi ikan pelagis kecil dan jumlah trip pukat cincin yang didaratkan di PPN Sibolga, 2010-2018.

Figure 9. Fluctuation of production of small pelagic fish and number of trips by purse seiners landed at PPN Sibolga, 2006-2018.

\section{Hasil per Unit Upaya (CPUE)}

Nilai CPUE ikan pelagis kecil di PPS Lampulo pada tahun 2007-2018 berfluktuatif. Rata-rata trip penangkapan selama 5 hari dan rata-rata CPUE sebesar 367 kg/hari. Nilai tertinggi (462 kg/hari) terdapat pada tahun 2018 dan terendah ( $251 \mathrm{~kg} / \mathrm{hari})$ pada tahun 2014.
Nilai CPUE ikan pelagis kecil di PPN Sibolga pada tahun 2010-2018 berfluktuatif. Rata-rata trip penangkapan selama 12,8 hari dengan rata-rata CPUE sebesar $392 \mathrm{~kg} / \mathrm{hari}$. Nilai tertinggi $(517 \mathrm{~kg} / \mathrm{hari})$ terdapat pada tahun 2016 dan terendah $(315 \mathrm{~kg} / \mathrm{hari})$ pada tahun 2017 (Gambar 10).

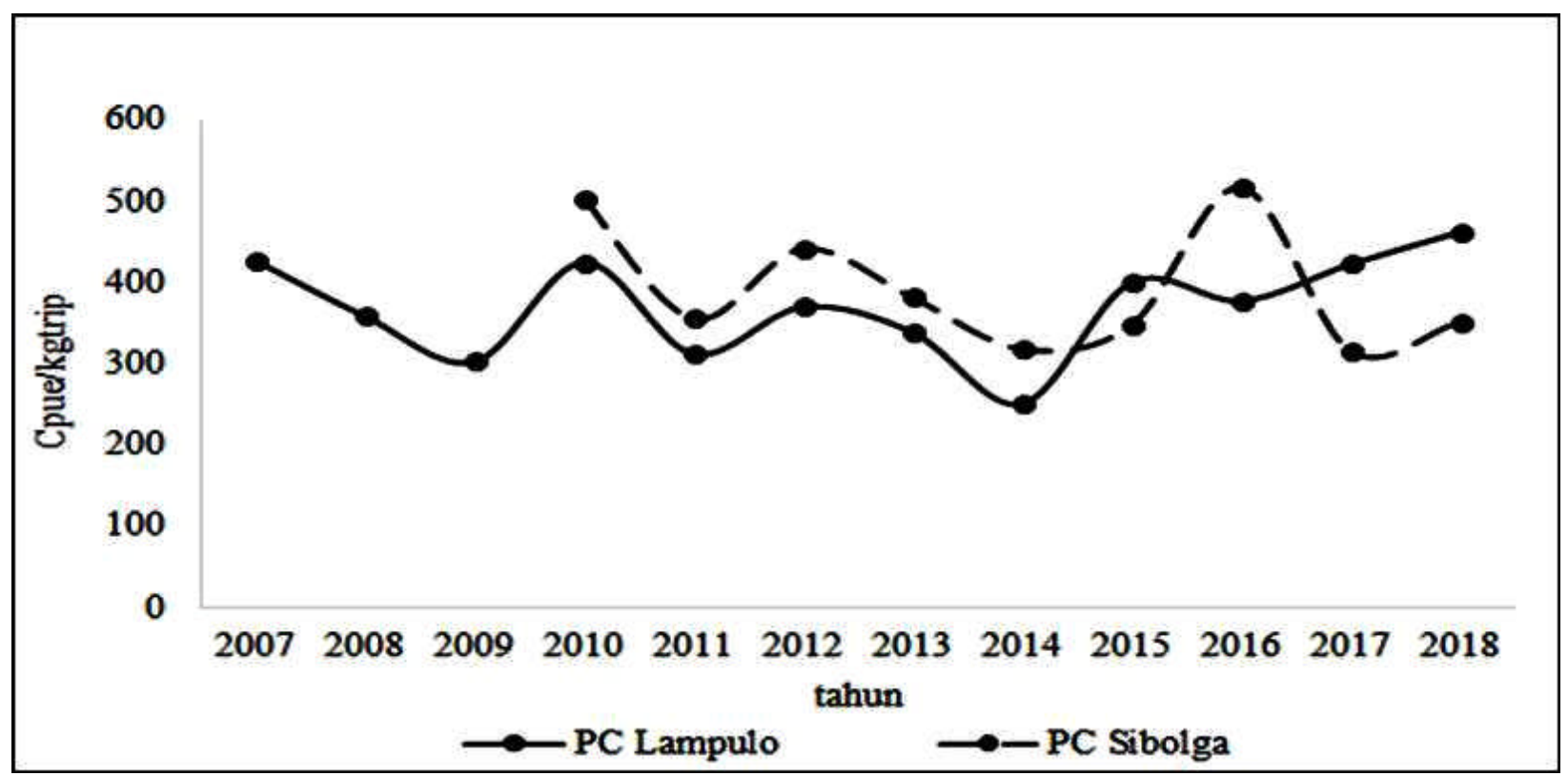

Gambar 10. Hasil per unit upaya pukat cincin yang didaratkan di Lampulo dan Sibolga, 2007-2018.

Figure 10. The CPUE of purse seiners landed at Lampulo and Sibolga, 2007-2018. 


\section{Bahasan}

Perubahan dimensi pukat cincin yang terjadi diperairan barat Sumatera terutama pada semakin bertambah panjangnya jaring yang digunakan. Perbedaan ukuran kedalaman jaring terkait dengan target penangkapannya. Untuk tujuan menangkap ikan pelagis besar mempunyai jaring dengan ukuran lebih dalam daripada jaring untuk menangkap ikan pelagis kecil. Kolom daerah berenang (swimming layer) kelompokan ikan pelagis besar di perairan Barat Sumatera berkisar antara $0-400 \mathrm{~m}$ dan ikan pelagis kecil antara 0-60m (Yusuf, 2016)

Dimensi alat tangkap pada realitasnya di barat Sumatera dari tahun ke tahun mengalami perubahan. Yang terjadi adalah dimensi ukuran panjang dan dalam pukat cincin pada 1992 yaitu panjang tali ris sekitar $654 \mathrm{~m}$ dan tali ris bawah $861 \mathrm{~m}$ dengan dalam jaring 45,8 m, ukuran mata jaring 1 inci untuk kantong (bunt), 1,5,2,0 dan 3,0 inci pada badan jaring (Bahar, 1994). Menurut Idham (2002) konstruksi jaring pukat cincin Banda Aceh adalah modivikasi dari pukat cincin tipe Amerika, dirancang berdasarkan atas kebiasaan nelayan dan disesuaikan dengan kondisi jarring untuk menangkap ikan perenang cepat.

Perikanan Pelagis kecil Lampulo dan Sibolga yang menggunakan pukat cincin umumnya dengan armada kapal bertonnase berkisar antara $6-100$ GT sedangkan tonnase 100 GT lebih umumnya di wilayah perbatasan ZEE Indonesia dan target sepesiesnya adalah pelagis besar. Kontribusi produksi tertinggi di Lampulo pada tonnase yang tidak tercatat yaitu sebesar $914.516 \mathrm{~kg}$, Sibolga tertinggi pada tonnase 61-100 GT sebesar 12.444,6 ton (BRPL, 2018). Dari total ikan hasil tangkapan pukat cincin Lampulo dan Sibolga, kontribusi perikanan pelagis kecil yang didaratkan di Lampulo dan Sibolga sebesar 50,24\% dan $29,8 \%$. Hasil ini menunjukkan bahwa secara umum penangkapan ikan pelagis kecil di Lampulo dan Sibolga cenderung terjadi di wilayah coastal dan teritorial Indonesia, yang merupakan daerah sebaran ikan pelagis kecil dan neritik tuna. Sedangkan armada pukat cincin Sibolga yang melakukan penangkapan di wilayah terittorial, ZEE Indonesia dan perbatasan, yang umumnya bertonnase di atas $100 \mathrm{GT}$, kapal nya dilengkapi frezeer dengan target penangkapannya adalah ikan pelagis besar.

Perkembangan waktu dan peningkatan permintaan pasar terhadap komoditas ikan pelagis kecil, berdampak terhadap perubahan armada penangkapan pukat cincin, yaitu pada 1994 umumya armada pukat cincin cakalang bertonnase 24 GT (Bahar, 1994); ar- mada penangkap pelagis kecil hanya 6 - 9 GT (Hariati et al., 2000); perkembangan tonnase pukat cincin Sibolga pada 1992 berkisar 20 - 130 GT dan 2003 berkisar 50 - $130 \mathrm{GT}$; armada pukat cincin Lampulo dari <10 GT menjadi 11-30 GT, sedangkan tonnase kapal penangkap tetap 19-30 GT, namun kekuatan mesin meningkat dari 40 PK menjadi 120 dan 160 PK (Hariati, 2011). Perubahan karakteristik armada pukat cincin Sibolga dalam komposisi ukuran dan jumlah disebabkan karena perubahan daerah penangkapan, meningkatnya permintaan dan tuntutan pasar (Hariati, 2003).

Daerah penangkapan ikan pelagis kecil Lampulo setiap tahunnya mengalami pergeseran ke wilayah yang lebih jauh. Pada 1995-1997 daerah penangkapan di sekitar utara atau barat daya Banda Aceh sampai dengan utara Pulau Sabang dan timur laut Sabang dengan trip 3-7 hari (Hariati, 2005a); Hariati et al. (2000). Perluasan daerah penangkapan pukat cincin saat ini selain di perairan Andaman, nelayan Lampulo sudah sampai perbatasan Pulau Nikobar dan terkadang sampai perbatasan India. Hal ini terlihat pada sebaran daerah penangkapan berdasarkan grid yaitu grid 97, 96, 50, 146 (Gambar 3). Secara persentase daerah penangkapan yang banyak dikunjungi terjadi lebih sering dalam grid 100 dan 101 (timur Pulau Nikobar atau Barat daya Aceh), artinya walaupun ada perluasan wilayah tangkapan, namun adanya kesamaan daerah penangkapan dari tahun tahun sebelumnya.

Sama halnya daerah penangkapan pukat cincin rapat di Sibolga mengalami perluasan wilayah yaitu pada 2003 sekitar perairan Simeulue, Pulau Banyak, perairan Tapanuli Tengah, sibolga sampai dengan Pulau Nias (Hariati, 2003). Dari hasil pengamatan berdasarkan data enumerator dan observer Sibolga, daerah penangkapan nelayan pukat cincin rapat di wilayah timur tercatat sampai dengan Kepulauan Mentawai, ZZE Indonesia dan perairan Simeulue. Berdasarkan grid daerah penangkapan, secara persentase perairan Simeulue dan Kep. Banyak lebih mendominasi sekitar 13,5-17\%.

Komposisi sumber daya ikan pelagis kecil yang tertangkap dengan pukat cincin dan bagan perahu, yaitu ikan layang, kembung, selar, tembang, lemuru, teri, sunglir dan ikan terbang. Berdasarkan Kep. Men. No. 50 (2017) potensi ikan pelagis kecil di WPP-572 diperkirakan sebesar 527 ribu ton dengan kontribusi sekitar $42,5 \%$ dari total potensi perikanan laut. Hal ini terlihat pada perkembangan produksi ikan pelagis di Lampulo pada $2006-2018$, dengan komposisi ikan layang sebesar $82,2 \%$, lemuru $6,5 \%$, selar $6,4 \%$ dan sunglir 4,8\% (BRPL, 2018). Sedangkan di PPN 
Sibolga, ikan layang sebesar $51 \%$, kembung $28 \%$, tembang $16 \%$ dan selar bentong 5\%. Hariati (2011) melaporkan bahwa ikan layang di perairan Barat Sumatera sebesar $20-35 \%$, bentong $13-16 \%$, tembang $5-16 \%$ dan siro 2-5\%; perairan Kendari, Laut Banda ikan layang sebesar 33-37,8\%, tembang $0,1-04 \%$ dan siro $0,1-0,2 \%$ (Hariati, 2011). Sementara diLaut Jawa dilaporkan sebesar 60\% (Triharyuni et al., 2014). Atmaja et al. (2001) menyebutkan bahwa ikan pelagis kecil yang tertangkap dengan pukat cincin di Laut Natuna mencapai $67,3 \%$ dengan rasio Decapterus russellidan Decapterus macrosoma (1:0,3).

Kontribusi produksi perikanan pelagis kecil di Lampulo pada 2006-2018 sekitar 47.190,3 ton, yaitu ikan layang (Decapterus macarellus) sebesar 26.768,3 ton, selar (Carangidae sp.) 1.931,3 ton, lemuru (Sardinella lemuru) 1.713,5 ton, kembung (Rastrelliger kanagurta) $1.887,5$ ton, tembang (Sardinella fimbriata) 1.373,5 ton, kambing-kambing (Canthidermis maculata) 2.123,5 ton, cumi-cumi (Photololligo duvaucelli) 1.635,5 ton dan sunglir (Elagatis bipinnulata) $1.837,3$ ton. Produksi pelagis kecil Sibolga tahun 2010 - 2018 sekitar 42.916,6 ton yaitu ikan layang (Decapterus macarellus) sebesar 14.250,4 ton, kembung (Rastrelliger kanagurta) 13.549 ton, tembang (Sardinella fimbriata) $5.307,3$ ton, selar bentong (Selar crumenopthalmus) 1.883,4 ton, japuh (Dussumieriasp) $3.810,5$ ton, tetengkek (Megalaspis cordyla) 1.468,5. Hariati et al. (2001) mengatakan bahwa hasil tangkapan ikan pelagis kecil barat Sumatera didominasi oleh ikan layang (Decapterus sp.), selar (Carangidae sp.), kembung (Rastrelliger kanagurta), siro (Amblygaster sirm), dan tembang (Sardinella fimbriata).

Hasil peneilitian Balai Riset Perikanan Laut (2004) menunjukkan bahwa hasil tangkapan pelagis kecil pukat cincin di Laut Jawa didominasi enam dari 16 jenis ikan. Potier \& Sadhotomo (1995a) melaporkan hasil tangkapan ikan pelagis kecil dengan pukat cincin mencapai $40 \%$. Selanjutnya Potier \& Sadhotomo (1995b) menyebutkan kontribusi ikan pelagis kecil dari tujuh spesies mencapai $90 \%$ dan ikan layang $60 \%$ (Decapterus russelli dan Decapterus macrosoma), banyar (Rastrellige rkanagurta) 18\%, siro (Amblygaster sirm) 7,4\%, bentong (Selar crumenophthalmus) $7 \%$, dan tembang (Sardinella gibbosa) $7 \%$; Zamroni \& Suwarso (2009) menyatakan bahwa ikan layang (Decapterus russelli dan Decapterus macrosoma) merupakan jenis ikan dominan yang tertangkap di setiap daerah penangkapan. Komposisi hasil tangkapan pukat cincin ikan pelagis di perairan Kendari Laut Banda adalah sekitar 33-38\% (Hariati et al., 2010); Hariati, 2011; Hariati, 2005; Kurnia 2016).
Suwarso (2008) mencatat perubahan komposisi spesies ikan pelagis kecil yang tertangkap oleh pukat cincin di Laut Jawa mungkin kurang nyata. Hal ini merujuk adanya fluktuatif hasil tangkapan pukat cincin yaitu ikan layang pada 1994 sebesar 56\%, tahun 2002-2006 berkisar 42 sampai dengan 57\% dan fluktuasinya ikan pelagis lainnya relatif sama.

Sebaran frekuensi panjang ikan yang tertangkap dengan pukat cincin di barat Sumatera tahun mengalami peningkatan, di mana pada 2003 kisaran panjang ikan layang berkisar antara $16-26 \mathrm{~cm} \mathrm{FL}$, selar bentong 7-21 dengan nilai Lc $21,9 \mathrm{~cm} \mathrm{FI}$ dan $14,7 \mathrm{~cm}$ FL (Hariati, 2005). Hasil penelitian 2018 sebaran ikan pelagis cenderung lebih besar yaitu ikan layang (Decapterus macarellus) berkisar antara 12,2 $-39,4 \mathrm{~cm}$ FL, selar bentong (Selar crumenopthalmus) $10,3-24 \mathrm{~cm}$ FL dan tembang (Sardinella fimbriata) $11-22 \mathrm{~cm} F L$, dengan nilai Lc layang $24 \mathrm{~cm} F L$, selar bentong $17 \mathrm{~cm}$ FL dan tembang $16 \mathrm{~cm}$ FL. Hal ini diduga karena ikan yang tertangkap pukat cincin ukuran besar berada di bawah sinar lampu pada malam hari, saat mana massa air oseanik tersebar di perairan Laut Jawa menjelang akhir tahun (Potier \& Sadhotomo, 1995). Lebih besarnya kisaran panjang pada 2018 dapat diduga karena luasnya daerah penangkapan pukat cincin pada areal lepas pantai dan cekungan cekungan laut dalam seperti yang diutarakan oleh Hariati (2005).

Perkembangan dan peningkatan kapasitas penangkapan baik dari ukuran kapal, teknologi penangkapan, kekuatan mesin, dan alat bantu penangkapan, sehingga cakupan dan ruang gerak pukat cincin dan bagan per tahun lebih luas ke wilayah lain. Hal ini ditunjukkan dengan meningkatnya jumlah trip penangkapan dan produksi. Peningkatan jumlah trip dan produksi di Lampulo pada 2006 - 2018 menunjukkan peningkatan yang signifikan, namun peningkatan trip terkadang tidak mempengaruhi terhadap produksi, yang mana pada 2010 jumlah tripnya sebanyak 2.084 trip dengan produksi sebesar 4.546,8 ton dan pada 2006 sebanyak 2.046 trip dengan produksi sebesar 3.210,2 ton. Sedangkan pukat cincin dan bagan perahu Sibolga menunjukkan pola peningkatan lebih baik yaitu pada 2016 sebanyak 1.232 trip dengan produksi sebesar $6.365,3$ ton meningkat sebesar $7.270,6$ ton. Pada 2018 tercatat 1.850 trip dan bagan per tahun tertinggi pada 2016 sebanyak 983 trip dengam produksi sebesar 1.991,5 ton dan pada 2018 sebanyak 932 trip dengan produksi sebesar 1.751,1 ton. Hariati (2011) menyatakan hasil tangkapan pukat cincin pelagis kecil di Banda Aceh pada 2008 sebesar 2.266 ton dan 2009 sebesar 2.902 ton. Hasil tangkapan ikan layang di perairan Kendari Laut Banda pada 2006 sebesar 2.267,4, pada 2007 
sebesar 3.133 ton dan 2008 mengalami penurunan sebesar 1.945 ton (Hariati et al., 2010).

Peningkatan aktivitas penangkapan (produksi dan trip) terjadi di Lampulo dan Sibolga, karena pencatatan atau logbooks tersistem dengan baik. Peningkatan aktivitas ini secara ekonomis tidak terlalu menguntungkan, karena tidak seimbang dengan biaya eksploitasi yang semakin besar. Peningkatan ratarata trip per kapal mengindikasikan jumlah hari operasi di laut lebih lama dan wilayah penangkapan semakin jauh. Semakin lama kapal pukat cincin di laut ternyata bukan merupakan penyebab kenaikan laju tangkap (Saadhotomo et al., 1986; Hufiadi, 2011). Suwarso et al. (2008) menyatakan bahwa peningkatan rata-rata jumlah hari operasi di laut nampak jelas terlihat di hampir seluruh daerah penangkapan utama, baik di Laut Jawa, Selat Makassar, sekitar Kangean, dan Laut Cina Selatan dan berdampak pada penurunan trip dan produksi. Sudjastani (1983) menyatakan bahwa produksi perikanan Barat Sumatera pada 1974-1976 rata-rata sebesar 65.000 ton/tahun, dua pertiga bagian merupakan produksi ikan pelagis kecil dengan alat tangkap payang, pukat pantai, jaring insang.

Perkembangan hasil tangkapan per unit upaya (CPUE) pelagis kecil pada 2018 di Lampulo dan Sibolga per bulannya mengalami fluktuasi. Nilai Cpue pukat cincin Lampulo rata-rata harinya sebesar 262,5 $\mathrm{kg} / \mathrm{tawur}$, Cpue pukat cincin Sibolga rata-rata perharinya sebesar $316,3 \mathrm{~kg} / \mathrm{tawur}$. Nilai Cpue ikan pelagis kecil di perairan utara Aceh, utamanya ikan layang mencapai $888 \mathrm{~kg} /$ trip, selar $780 \mathrm{~kg} /$ trip, siro 504 kg/trip layang abu-abu 362 kg/trip (Kurnia, 2016; Hariati, 2000; Hariati, 2011; Zamroni \& Suwarso, 2009). Hariati (2001) menyatakan jumlah rata-rata hari efektif kapal pukat cincin pada 1992-1994 di lima daerah penangkapan perairan Aceh Selatan sebanyak 13.243 hari dengan rata-rata laju tangkap perhari sebesar 413,1 kg pertawur. Di perairan barat Sumatera catch per unit of effort total pukat cincin rapat pada Januari sampai Juli tahun 2005 (pasca tsunami) sebesar $1.087 \mathrm{~kg} /$ tawur, naik dibandingkan dengan Januari sampai Juli tahun 2003 (pra tsunami) yaitu $673 \mathrm{~kg} /$ tawur yang disebabkan turunnya jumlah upaya. Catch per unit of effort ikan layang Decapterus russellidan Decapterus macrosoma) relatif tetap, catch per unit of effort jenis jenis ikan banyar, bentong (Selar crumenophtalmus), tetengkek (Megalapsis cordyla), dan tembang naik, sedangkan catch per unit of effort ikan tongkol turun (Hariati \& Sadhotomo, 2007).

\section{KESIMPULAN}

Perkembangan waktu dan peningkatan pemanfaatan terhadap hasil perikanan khususnya pelagis kecil di perairan barat Sumatera, berdampak terhadap pada perubahan dimensi alat tangkap pukat cincin yang berdampak terhadap pergeseran daerah penangkapan yang cenderung lebih jauh dari sebelumnya, secara umum wilayah lama masih mendominasi di wilayah P. Nikobar, Kepulauan Mentawai dan ZEE Indonesia di Lampulo dan Sibolga. Pergerseran daerah penangkapan ikan menyebabkan peningkatan proporsi hasil tangkapan ikan layang di atas 50\% yaitu Lampulo sebesar $82,2 \%$ dan Sibolga $51 \%$, dimana daerah penangkapannya cenderung di wilayah pesisir dan teritorial Indonesia, yang merupakan sebaran ikan pelagis kecil dan neritic. Pergeseran daerah penangkapan dapat juga terlihat dari perubahan nilai Lc ikan layang, selar bentong dan tembang yang cenderung lebih besar yaitu sebesar $24,27 \mathrm{~cm}$ FL, $17,45 \mathrm{~cm}$ FL, dan $16,6 \mathrm{~cm}$. Meningkatnya nilai Lc ternyata tidak mempengaruhi terhadap nilai Cpue yang cenderung lebih kecil dari tahun tahun sebelumnya yaitu sebesar $263 \mathrm{~kg} / \mathrm{hari}$ Lampulo dan 316 kg/hari untuk Sibolga.

\section{PERSANTUNAN}

Tulisan ini merupakan kontribusi dari kegiatan hasil riset pengkajian habitat, biologi, dan stok sumberdaya ikan serta karakteristik di WPP 572 Barat Sumatera Samudera Hindia, T. A. 2018, di Balai Riset Perikanan Laut Cibinong, Bogor. Penulis mengucapkan terimakasih kepada Kepala Pelabuhan Perikanan Samudera Lampulo, Banda Aceh, beserta staf Sdr. Kamil Sayuti, Sdr. Tommy, dan Sdr. Musda serta ibu Krisiswanti (Sibolga), atas bantuan dan kerjasama selama survey ini yang berlangsung pada 2018. Kontributor utama dalam publikasi ilmiah ini adalah Helman Nur Yusuf.

\section{DAFTAR PUSTAKA}

Atmaja, S. B., Wiyono, E. S., \& Nugroho, D. (2001). Karakteristik Sumber Dayalkan Pelagis Kecil di Laut Cina Selatan dan Perkembangan Eksploitasinya. Buletin PSP. Vol. X. No. 1. Hal. 51-64.

Bahar, S. (1994). Studi teknologi pukat cincin cakalang di perairan Daerah Istimewa Aceh. Jurnal Penelitian Perikanan Laut. 85: 9-18.

Balai Riset Perikanan Laut. (2004). Musim penangkapan ikan di Indonesia. Departemen Kelautan dan Perikanan. Jakarta. 116 pp.

Balai Riset Perikanan Laut. (2018). Laporan teknis penelitian karakteristik biologi perikanan, habitat sumberdaya dan potensi produksi sumber daya 
ikan di WPP 572. Kementerian Kelautan dan Perikanan. Cibinong. 218 pp.

Gloerfelt, T., \& Kailola, T. P. J. (1980). Trawled fishes of Southern Indonesia Nad Northwestern Australia. The Australian Development Assistance Bureau-The Directorate General of Fisheries, Indonesia-The German Agency or Technical Cooperation

Hariati, T., Girsang, E. S., \& Nugroho, D. (2000). Perkembangan pukat cincin di Selat Malaka. J.Lit.Perikan.Ind. 6 (2): 43-52. DOI: http:// dx.doi.org/10.15578/jppi.6.2.2000.43-52

Hariati, T., Sriyati, E., \& Mardliyah, S. (2001). Perubahan musiman komposisi hasil tangkapan dan kelimpahan ikan pelagis kecil di perairan Selat Malaka. J.Lit.Perikan.Ind. 7 (1): 53-61.

Hariati, T. (2005). Perkembangan Pemanfaatan Ikan Pelagis Kecil Mengunakan Pukat Cincin Sibolga Di Perairan Barat Sumatera Pada Tahun 2003. Jurnal Penelitian Perikanan Laut. 11(2): 57-67.

Hariati, T. (2005a). Ikan Layang Biru (Decapterus macarellus), salah satu spesies ikan pelagis kecil laut dalam di Indonesia. Dalam Warta Penelitian Perikanan Indonesia Edisi Sumber daya dan Penangkapan. BRKP - DKP: hal. 15-22.

Hariati, T., \& Sadhotomo, B. (2007). Aktivitas kapal pukat cincin Sibolga tahun 2002-2005 dan laju tangkap pukat rapat dan pukat jarang pada periode bulan Januari sampai Juli 2005 (pasca tsunami). J.Lit.Perikan.Ind. 13(3), 179-190. DOI: http:// dx.doi.org/10.15578/jppi.13.3.2007.179-190

Hariati, T., Amri, K., \& Chodriyah, U. (2010). Fluktuasi hasil tangkapan ikan laying (Decapterus spp.) di perairan Kendari dan sekitarnya serta kaitannya dengan sebaran suhu permukaan laut, salinitas, dan kandungan klorofil-a permukaan. J.Lit.Perikan.Ind. 16(2), 135-146. DOI: http:// dx.doi.org/10.15578/jppi.16.2.2010.135-146

Hariati, T. (2011). Status dan perkembangan perikanan pukat cincin di Banda Aceh. Jurnal Penelitian Perikanan Laut. 17(3), 157-167. DOI:http:// dx.doi.org/10.15578/jppi.17.3.2011.157-167

Hariati, T. (2011). Komposisi hasil tangkapan, musim penangkapan, dan indeks kelimpahan ikan pelagis yang tertangkap pukat cincin mini di Perairan Kendari, Laut Banda. Jurnal Penelitian Perikanan Laut. 17(2), 139-146. DOI:http://dx.doi.org/ 10.15578/jppi.17.2.2011.139-146
Hariati, T. (2011). Perkembangan Perikanan Pelagis Kecil Hasil Tangkapan Pukat Cincin dan Bagan di Perairan Barat Sumatera. Jurnal Penelitian Perikanan Laut. 17(4), 229-235. DOI: http:// dx.doi.org/10.15578/jppi.17.4.2011.229-235

Hufiadi., Mahiswara., \& Budiarti, T. W. (2011). Tingkat efisiensi kapasitas perikanan pukat cincin di Banda Aceh. Jurnal Penelitian Perikanan Laut. 17(3), 169-175. Ol:http://dx.doi.org/10.15578/ jppi.17.3.2011.169-175

Idham. (2002). Desain konstruksi purse seine Aceh di Lampulo Kota Banda Aceh. Thesis. Fakultas Perikanan. Universitas Abul Yatama. Aceh Besar. 50pp.

Keputusan Kementrian Kelautan dan Perikanan Republik Indonesia. (2017). Nomor Kep. 50/ KEPMEN-KP/2017 Tentang Estimasi Potensi, Jumlah Tangkapan yang di perbolehkan, dan Tingkat Pemanfaatan Sumber Daya Ikan di Wilayah Pengelolaan Perikanan Negara Replubik Indonesia. 7 hal.

Kurnia., Purnawan, S., \& Rizwan, T. (2016). Pemetaan Daerah Penangkapan Ikan Pelagis Kecil Di Perairan Utara Aceh. Jurnal IImiah Kelautan dan Perikanan Unsyiah. 1(2), 185-194.

Nurhakim, S., Nickijuluw, V. P. H., Nugroho, D., \& Prisantoso, B. I. (2007). Wilayah pengelolaan perikanan: status perikanan menurut wilayah pengelolaan. Informasi Dasar Pemanfaatan Berkelanjutan. Buku 2. Pusat Riset Perikanan Tangkap. Badan Riset Kelautan dan Perikanan. Departemen Kelautan dan Perikanan. 47 pp.

Potier, M., \& Sadhotomo, B. (1995a). Seiners fisheries in Indonesia. In Potier, M. \& Nurhakim, S (eds). BIODINEX: Biology, Dynamics, Exploitation of the Small Pelagic Fishes in Java Sea. AARD/ ORSTOM. 49-66. http://www.documentation.ird.fr/hor/fdi:42766

Potier, M., \& Sadhotomo, B. (1995b). Exploitation of the large and medium seiners fisheries in the Java Sea. In Potier, M. \&Nurhakim, S (eds). BIODINEX: Biology, Dynamics, Exploitation of the Small Pelagic Fishes in Java Sea. AARD/ORSTOM. 195214. http://www.documentation.ird.fr/hor/fdi:42773

Sadhotomo, B., Nurhakim, S., \& Atmadja, S. B. (1986). Perkembangan Komposisi Hasil Tangkapan dan Laju Tangkap Pukat Cincin Di Laut Jawa. Jurnal Penelitian Perikanan Laut. BPPL. Jakarta. (35), 101-109. 
Suman, A., Wudianto., Sumiono, B., Irianto, H. E., Badrudin., \& Amri, K. (2014). Potensi lestari tingkat pemanfaatan sumber daya ikan di Wilayah Pengelolaan Perikanan Republik Indonesia (WPP RI) (p. 199). Penerbit Ref Grafika, Jakarta.

Suwarso., Wudianto., \& Atmadja, S.B. (2008). Hasil tangkapan ikan pelagis kecil di sekitar Laut Jawa: Kajian Paska Kolaps Perikanan Pukat Cincin Besar. BAWAL Widya Riset. 2(1), 17-26. DOI: http://dx.doi.org/10.15578/ bawal.2.1.2008.17-26

Sudjastani, T. (1983). Pengembangan Usaha Perikanan Laut di Sumatera. Laporan Penelitian Perikanan Laut. No.28, 1-12
Triharyuni, S., Hartati, S.T., \& Nugroho, D. (2014). Evaluasi Potensi Ikan Layang (Decapterus Spp.) Di WPP 712-Laut Jawa. J.Lit.Perikan.Ind. 20(3), 143-152. DOI:http://dx.doi.org/10.15578/ jppi.20.3.2014.143-152

Yusuf, H. N. (2016). Karakteristik teknis pukat cincin, pengaruhnya terhadap hasil tangkapan di Pacitan Jawa Timur, Tesis. Institut Pertanian Bogor. 52 pp

Zamroni, A., \& Suwarso. (2009). Perkembangan hasil tangkapan ikan pelagis kecil di sekitar Laut Jawa. J.Lit.Perikan.Ind. 15(4), 307-312. DOI:http:// dx.doi.org/10.15578/jppi.15.4.2009.307-312 
Lampiran 1. Spesifikasi purse seine dan aspek operasional berbasis Lampulo dan Sibolga

Appendix 1. Specification of purse seine nets and its operational aspects based at Lamulo and Sibolga

\begin{tabular}{|c|c|c|c|}
\hline \multirow[b]{2}{*}{ No } & \multirow[b]{2}{*}{ Parameter } & \multicolumn{2}{|c|}{ Spesifikasi/Specification } \\
\hline & & $\begin{array}{l}\text { Lampulo } \\
\text { PS Pelagis Kecil }\end{array}$ & $\begin{array}{c}\text { Sibolga } \\
\text { PS Pelagis Kecil }\end{array}$ \\
\hline 1 & Bahan utama & Kayu & Kayu \\
\hline & Dimensi utama Kapal : & $\begin{array}{l}\text { KM. Laut Subur Baroe } 29 \text { GT } \\
\text { No. 28/QQC }\end{array}$ & $\begin{array}{l}\text { KM. Surya Jaya } 59 \text { GT No. } \\
\text { 1344/SSD }\end{array}$ \\
\hline & Panjang $(\mathrm{P}) / \mathrm{m}$ & $17 \mathrm{~m}$ & 27 \\
\hline 2 & Lebar (L)/m & $3,5 \mathrm{~m}$ & 4,5 \\
\hline & Dalam (D)/m & 2,5 & 3 \\
\hline & GT (Ton) & 29 & 59 \\
\hline 3 & Alat tangkap & 8 pis (1"-2") & 10 pis (1"- 2,5 “) \\
\hline 4 & $\begin{array}{l}\text { Panjang tali ris atas / bawah } \\
\text { (m) }\end{array}$ & $480 / 528$ & $600 / 660$ \\
\hline 5 & Bahan jaring & nylon multifilamen twine D16 & nylon multifilamen twine D16 \\
\hline 6 & Jumlah Cincin & 132 (uk. 3 " ketebalan $\varnothing 0,65 "$ ) & 132 (uk. 3 " ketebalan $\varnothing 0,65 "$ ) \\
\hline 7 & Jumlah Pemberat & 270 buah & 264 buah \\
\hline 8 & ABK (orang) & 20 orang & 28 orang \\
\hline 9 & Daerah penangkapan & $\begin{array}{l}\text { Perairan Andamanan, Kep. } \\
\text { Nikobar }\end{array}$ & $\begin{array}{l}\text { Perairan Mursala, Nias, Kep. } \\
\text { Banyak, Samudera Hindia }\end{array}$ \\
\hline 10 & Pelabuhan Pangkalan & PPS Lampulo & Sibolga \\
\hline 11 & Jumlah hari di laut/trip & 3-6 hari & 10-17 hari \\
\hline 12 & $\begin{array}{l}\text { Jumlah hari efektif operasi } \\
\text { alat tkp. }\end{array}$ & $2-5$ hari & 5-13 hari \\
\hline 13 & Jumlah tawur per hari & $\begin{array}{l}1-2 \text { kali } \\
3-10 \text { ton }\end{array}$ & $\begin{array}{l}1-2 \text { kali } \\
5-13 \text { ton (musimTimur) }\end{array}$ \\
\hline 14 & Total hasil tangkapan (Ton) & $4-12$ ton & $7-18$ ton (musimBarat) \\
\hline 15 & $\begin{array}{l}\text { Jenis ikan hasil tangkapan } \\
\text { dominan }\end{array}$ & $\begin{array}{l}\text { Layang, cakalangn, baby tuna, } \\
\text { kembung, selar }\end{array}$ & $\begin{array}{l}\text { layang, cakalang, tuna, tongkol } \\
\text { krai, komo, lemuru, kembung } \\
\text { dan selar }\end{array}$ \\
\hline 16 & $\begin{array}{l}\text { Sistim Palkah } \\
\text { (es/kompresor) }\end{array}$ & Es & 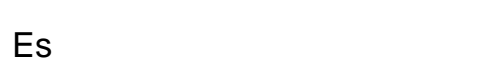 \\
\hline 17 & Kapasitas Palkah (ton) & 2 ton & 4 ton \\
\hline 18 & Gaji ABK @ hari & $\begin{array}{l}\text { Bagi hasil ( } 60 \text { opersional : } 40 \\
\text { abk,pemilik) }\end{array}$ & $\begin{array}{l}\text { Bagi hasil ( } 60 \text { opersional : } 40 \\
\text { abk,pemilik) }\end{array}$ \\
\hline 19 & Premi ABK @ 1 ton & & 12,000 \\
\hline 20 & Jumlah lampu & 14 (500 watt) & 19 (500 watt), 3(1000watt) \\
\hline 21 & Rumpon & $3-5 \mathrm{bh}$ & $5 \mathrm{bh}$ \\
\hline 22 & Panjang Rumpon & $800-2000 m$ & $1500-2500 m$ \\
\hline 23 & Perbekalan kapal (Rp) & 23,5 juta & 34 juta \\
\hline 24 & BBM Solar & $2-3$ ton & 8 ton \\
\hline 21 & Mesin Utama & Mitsubishi 160 PK & Mitsubishi 160 PK \\
\hline 22 & Mesin Bantu & Mitsubishi 42 PK & Mitsubishi 42 PK \\
\hline
\end{tabular}

